九州大学学術情報リポジトリ

Kyushu University Institutional Repository

\title{
Developmental 'Changes in Activities of Several Enzymes Involved in Glycolysis and TCA Cycle during the Pupal Period of Bombyx mori
}

Miake, Fumio

Laboratory of Sericultural Chemistry, Faculty of Agriculture, Kyushu University

Torikata, Takao

Laboratory of Sericultural Chemistry, Faculty of Agriculture, Kyushu University

Hanada, Shuichi

Laboratory of Sericultural Chemistry, Faculty of Agriculture, Kyushu University

Soeda, Ei ichi

Laboratory of Sericultural Chemistry, Faculty of Agriculture, Kyushu University

他

https://doi.org/10.5109/22896

出版情報 : 九州大学大学院農学研究院紀要. 20 (3/4)，pp. 143-149，1976-10. Kyushu University バージョン：

権利関係 : 


\title{
Developmental 'Changes in Activities of Several Enzymes Involved in Glycolysis and TCA Cycle during the Pupal Period of Bombyx mori
}

\author{
Fumio M iake, Takao Torikata, Shuichi Hanada*, Eiichi Soeda**, \\ $\mathrm{K}$ atsumi $\mathrm{K}$ oga and $\mathrm{K}$ atsuya $\mathrm{H}$ ayashi \\ Laboratory of Sericultural Chemistry, Faculty of Agriculture, \\ Kyushu University, Fukuoka
}

(Received May 14, 1976)

\begin{abstract}
In order to elucidate metabolic regulation with regard to carbohydrates and lipids during metamorphosis of Bombyx mori, eight enzymes related to glycolysis and TCA cycle were measured for their levels of activity during the period from the day of pupal ecdysis to 2 days after adult emergence, by use of crude extract from the whole bodies of the insect. The resulting patterns could be grossly divided into two groups. Glucose-B-phosphate dehydrogenase, NADP-specific isocitrate dehydrogenase, malic enzyme, hexokinase and pyruvate kinase were characterized by their apparent high activity levels during larval-pupal development followed by low levels at emergence. On the contrary, aconitase, NAD-specific isocitrate dehydrogenase and malate dehydrogenase were characterized by their apparent low levels during pupal period and by an abrupt increase in activity before emergence. The roles of these enzymes in metamorphosis are briefly discussed.
\end{abstract}

\section{INTRODUCTION}

Recently, attention has been focused on metabolic conversions underlying the remarkable, morphological changes during the development of insects (Morishima, 1975; Walker and Bailey, 1970; Yamashita and Hasegawa, 1974). In metamorphosing endopterigote insects like the silkworm, certain larval tissues are degraded and regenerated into a new form adaptable to the adult life. Such a process must be controlled by highly ordered, elaborate systems of decomposition and reconstruction which are closely correlated with each other. The regulatory mechanisms concerning the system may be approached by an enzymological study. The enzymes involved in the glycolytic pathway and TCA cycle will be of primary importance. The present paper deals with the changes in activity levels for the several of these enzymes in the crude extracts from the developing pupae of Bombyx mori.

Present address: * Central Research Laboratories of Green Cross Corporation, Miyakojima, Osaka 534.

** National Institute of Genetics, Mishima 411. 


\section{MATERIALS AND METHODS}

\section{Materials}

NAD*, NADP, glucose-6-phosphate, phosphoenolpyruvate, ADP and ATP were obtained commercially (Boehringer, Mannheim). Malate dehydrogenase, glucose-6-phosphate dehydrogenase and lactate dehydrogenase used for coupling reactions were the products of Boehringer, Mannheim. Other reagents were of analytical grade.

\section{Preparation of crude extract}

Hybrid strains of the silkworm were used. Ten individuals were taken at intervals during the developmental stage from the day of larval-pupal ecdysis to 2 days after adult emergence. Male and female animals were separately processed. The pooled silkworms were weighed and homogenized with a Waring blender in three volumes per weight of a solution composed of $0.1 \mathrm{M}$ $\mathrm{KCl}, 0.01 \mathrm{M}$ sodium phosphate buffer ( $\mathrm{pH}$ 7.0) and $1 \mathrm{mM} 2$-mercaptoethanol. The homogenate was passed through double layers of gauze and centrifuged at $8000 \mathrm{x} \mathrm{g}$ for $25 \mathrm{~min}$. The supernatant was subjected to spectrophotometric assay of enzymatic activity as described below.

\section{Measurement of enzymatic activity}

Activities of the enzymes were routinely assayed by use of a spectrophotometer in a cell with a light path of l-cm, by recording an increase or a decrease in the absorbance of a UV-absorbing substrate, product, or coenzyme. A Hitachi 124 spectrophotometer equipped with a recorder and a temperature controlling cell-holder was used. As to all the enzymes concerned the changes in the absorbance were linear during the first several minutes of reaction: the initial velocities of the enzymatic reaction could be calculated by the gradient of the recorded curves. One unit of an enzyme was defined as its amount that caused the change of $1 \mu$ mole of the substrate or so (see above) used for the spectrophotometry per min per $\mathrm{ml}$ at $30^{\circ} \mathrm{C}$.

\section{Glucose-6-phosphate dehydrogenase}

Enzymatic activity for this was measured in $0.1 \mathrm{M}$ Tris- $\mathrm{HCl}$ buffer ( $\mathrm{pH} 7.5$ ) containing $0.5 / *$ moles of glucose-6-phosphate, $1.0 \mu$ mole of $\mathrm{MgCl}_{2}$ and $1.0 \mu$ mole of NADP in a total volume of $3.0 \mathrm{ml}$. The reaction was initiated by the addition of 10 or $25 \mu \mathrm{l}$ of the extract. Formation of NADPH was estimated by the absorbance at $340 \mathrm{~nm}$.

\section{NADP-specific isocitrate dehydrogenase}

Activity of the enzyme was measured by an increase in the absorbance at $340 \mathrm{~nm}$ of $\mathrm{NADPH}$. The mixture used was composed of $0.1 \mathrm{M}$ Tris- $\mathrm{HCl}$ buffer

* Abbreviations used are: NAD, nicotinamide-adenine dinucleotide; NADH, reduced form of NAD; NADP, nicotinamide-adenine dinucleotide phosphate; NADPH, reduced form of NADP; ADP, adenosine-5'-diphosphate; ATP, adenosine-5'-triphosphate; G6P-DH, glucoseg-phosphate dehydrogenase; NAD-ICDH, isocitrate dehydrogenase specific for NAD; NADPICDH, do. specific for NADP; ME, malic enzyme; HK, hexokinase; PK, pyruvate kinase; $\mathrm{MDH}$, malate dehydrogenase. 
(pH 7.8) containing $0.5 \mu$ moles of DL-isocitrate, $1.0 \mu$ mole of $\mathrm{MnCl}_{2}$ and 0.1 $\mu$ moles of NADP in a total volume of $3.0 \mathrm{ml}$. The reaction was initiated by the addition of 10 or $25 \mu l$ of the extract.

\section{Malic enzyme}

Activity of the enzyme was measured in $0.05 \mathrm{M}$ Tris- $\mathrm{HCl}$ buffer ( $\mathrm{pH} 7.5$ ) containing $10 \mu$ moles of malate, $0.5 \mu$ moles of NADP and $5 \mu$ moles of $\mathrm{MnCl}_{2}$ in a total volume of 3 . Oml. The reaction was initiated by the addition of 10 to $50 \mu 1$ of the extract. Production of NADPH was measured by the absorbance at $340 \mathrm{~nm}$.

\section{Hexokinase}

Production of glucose-6-phosphate from glucose by the enzyme was coupled with the reaction of added glucose-6-phosphate dehydrogenase and was measured by an increase in the absorbance of NADPH at $340 \mathrm{~nm}$. The reaction mixture used was made up of $\mathbf{0 . 1} \mathrm{M}$ Tris- $\mathrm{HCl}$ buffer ( $\mathrm{pH} 7.5), 666 \mu$ moles of glucose, 20 umoles of $\mathrm{MgCl}_{2}, 8.1 \mu$ moles of ATP, $2.2 \mu$ moles of NADP and 1.5 units of glucose-6-phosphate dehydrogenase in a total volume of $3.0 \mathrm{ml}$. The reaction was initiated by the addition of $100 \mu$ l of the extract.

\section{Pyruvate kinase}

Production of pyruvate from phosphoenolpyruvate by the enzyme was coupled with the reaction of added lactate dehydrogenase and was spectrophotometrically followed by a decrease in the absorbance of $\mathrm{NADH}$ at $340 \mathrm{~nm}$. The reaction mixture used for this consisted of $0.1 \mathrm{M}$ Tris- $\mathrm{HCl}$ buffer ( $\mathrm{pH}$ 7. 6), 1.6 $\mu$ moles of phosphoenolpyruvate, $7.5 \mu$ moles of $\mathrm{MgSO}_{4}, 30 \mu$ moles of KCI, $14.1 \mu$ moles of ADP , 0.6 $\mu$ moles of $\mathrm{NADH}$ and 45 units of lactate dehydrogenase in a total volume of $3.0 \mathrm{ml}$. The reaction was initiated by the addition of $20 \mu \mathrm{l}$ of the crude enzyme solution.

\section{Aconitase}

The reaction was started by the addition of less than $50 \mu 1$ of the extract to $3 \mathrm{ml}$ of a solution containing $10 \mu$ moles of DL-isocitrate in $0.05 \mathrm{M}$ potassium phosphate buffer ( $\mathrm{pH} 7.5)$. The initial increase in the absorbance at $240 \mathrm{~nm}$ that was caused by the formation of aconitate from isocitrate was measured according to the method previously reported (Soeda et al., 1973).

\section{NAD-specific isocitrate dehydrogenase}

The reaction mixture used for the enzyme was composed of $0.05 \mathrm{M}$ Tris$\mathrm{HCl}$ buffer ( $\mathrm{pH} 7.0$ ), $20 \mu$ moles of DL-isocitrate, $3 \mu$ moles of NAD and $15 \mu$ moles of $\mathrm{MgCl}_{2}$ in a total volume of $3.0 \mathrm{ml}$. The reaction was initiated by the addition of 10 or $50 \mu$ l of the extract. An increasing amount of NADH was measured in the absorbance at $340 \mathrm{~nm}$.

\section{Malate dehydrogenase}

Activity for the enzyme was measured in $0.05 \mathrm{M}$ Tris- $\mathrm{HCl}$ buffer ( $\mathrm{pH} 7.5$ ) containing $10 \mu$ moles of oxaloacetate and $1.3 \mu$ moles of $\mathrm{NADH}$ in a total volume of $3.0 \mathrm{ml}$. The reaction was initiated with 10 or $20 \mu \mathrm{l}$ of the extract, and a decrease in the absorbance of NADH was measured at $340 \mathrm{~nm}$. 


\section{RESULTS AND DISCUSSION}

Many different patterns of activity were observed for different enzymes during developmental stage, they could be, however, grossly divided into two groups. A group of enzymes, GGP-DH, NADP-ICDH, ME, HK and PK, was characterized by their apparent high levels during larval-pupal development and low levels at emergence. The activities of GGP-DH (Fig. l-A), NADP-ICDH (Fig. 1-B) and ME (Fig. 1-C) gradually decreased just after pupation and increased gradually on 3rd to 6th days of the pupal period. At 6 days of age,
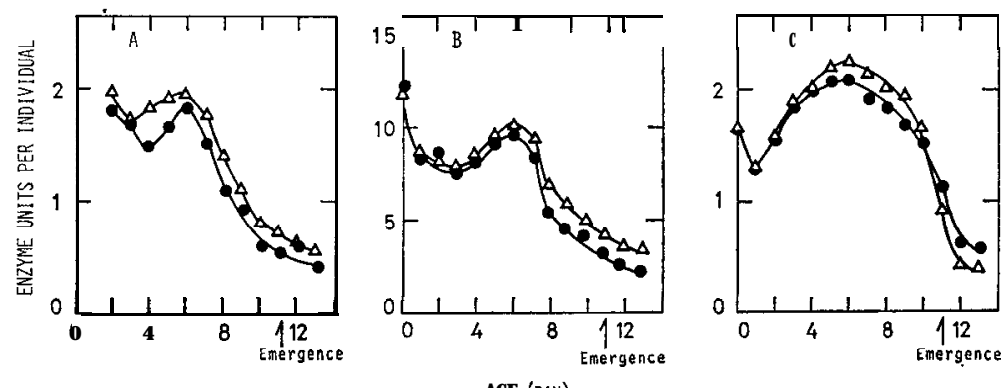

Fig. 1. Changes of GGP-DH (A), NADP-ICDH (B) and ME (C) activity during pupal period. . male, $\Delta$ female.

the activities took their maximum values and gradually decreased thereafter. No significant differences between males and females occurred with the three enzymes. The HK activity (Fig. 2-A) decreased till 3 to 4 days of age and later increased gradually, reaching its maximum level at day 7 of development. Then the activity decreased gradually till emergence. The activity level was slightly higher in females than that of males. The activity of PK (Fig. 2-B)
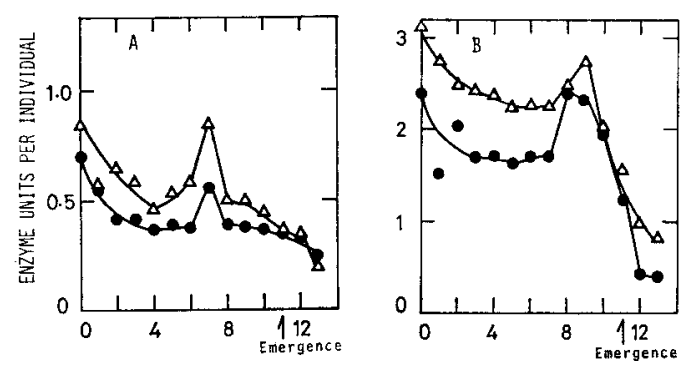

ACE (DAY)

Fig. 2. Changes of HK (A) and PK (B) activity during pupal period.

- male, $\Delta$ female.

gradually decreased during the period from pupation to 6 or 7 days of development and attained to a maximum value at 9 days of age, then it decreased steeply. The enzyme showed higher activity in females than in males.

Another group of enzymes, aconitase (Fig. 3-A), NAD-ICDH (Fig. 3-B) and 


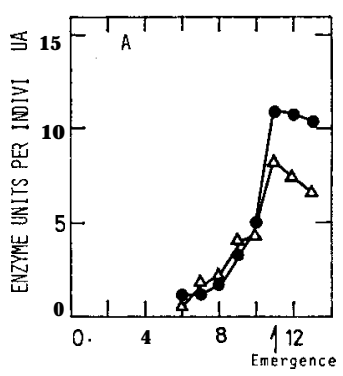

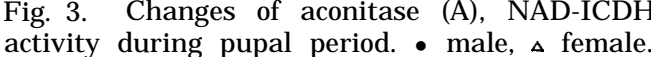
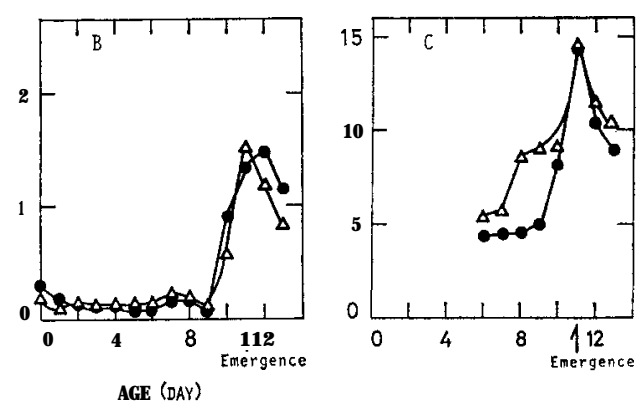

(B) and $\mathrm{MDH}(\mathrm{C})$

MDH (Fig. 3-C), was characterized by their apparent low levels during pupal period and by a remarkable rise in the activity shortly before emergence. The activities of NAD-ICDH and $\mathrm{MDH}$ showed their maximum values just at the time of emergence and then decreased gradually, while the aconitase activity remained high after emergence. No significant differences between males and females were observed.

It has been shown that a number of metabolites, including cyclic nucleotides (Kafatos, 1975), carbohydrates (Wyatt, 1967; Yamashita and Hasegawa, 1974), lipids and fatty acids (Ichimasa, 1975; Ichimasa and Hasegawa, 1973), attain interesting fluctuation patterns in accordance with the pupal-adult development of certain silkmoths and Bombyx mori. Only a few investigators, however, have pointed out the correlations of these changes to their related enzymes, as shown in studies on the glycogen-trehalose system (Wyatt, 1967; Yamashita and Hasegawa, 1974; Yamashita et al., 1974). It is well known that absorption of oxygen by many insects changes in a U-shaped curve during pupal age. As this holds also for Bombyx mori (Nittono and Nakasone, 1955; Kobayashi, 1957), it is easily presumed that in the same species the activities of the enzymes that are involved in TCA cycle are low during the middle stage of the pupa, and increase at the end of the pupal age or just after emergence. The present experiments showed that the activities of aconitase, NAD-ICDH and MDH abruptly increased at emergence, although they slightly increased 2 to 4 days before emergence. At the time of emergence, the thoracic muscles attain rapid development of sarcosomes, which correspond to mitochondria in biochemical actions. Moreover, there was evidence that the aconitase was of a sarcosomal origin (Soeda et al., 1973). These facts support the concept that aforementioned enzymes may play their parts in respiration and that activation or biosynthesis of these enzymes may be a critical step for the differentiation of the muscles.

Contrary to above, the activities of G6P-DH, NADP-ICDH and ME were maximum at 6 days of age and that of $\mathrm{HK}$ was maximum at day 7 in Bombyx mori (Figs. l-A, B, C and Z-A). During these periods, aerobic respiration systems in this insect may be low in activity (Nittono and Nakasone, 1955; Kobayashi, 1957), but histolysis and histogenesis with concomitant degradation and regeneration of carbohydrates (Yamashita and Hasegawa, 1974), lipids and 
fatty acids (Ichimasa, 1975 ; Ichimasa and Hasegawa, 1973), nucleic acids (Chinzei and Tojo, 1972) and proteins (Tojo, 1971) are actively taking place. It is also probable that the cuticle chitin of the larva degrades during larvalpupal ecdysis and some part of it may be stored in the form of glycogen or so for the reconstruction of the adult cuticles as was shown for Hyalophora cecropia (Bade and Wyatt, 1962). A part of the energy for these processes may be supplied by NADPH, which is conceivably produced by the action of GGP-DH, $\mathrm{ME}$ and NADP-ICDH.

The activity of PK was maximum in pupae of 9 days old, and it is possible that the enzyme may supply pyruvate which can serve as a starting point for synthetic pathways such as those for fatty acids and amino acids. In fact, it was shown that fatty acid composition in the glycerides changes significantly during pupal age of Bombyx mori (Ichimasa, 1975; Ichimasa and Hasegawa, 1973; Nakasone and Ito,1967), and this is taken to indicate that fatty acids are synthesized at least to some extent in the pupal tissues, although these substances accumulate most abundantly during the last larval instar (Shigematsu and Takeshita, 1959).

During pupal-adult development, the fat body and the ovaries exhibit glycolysis and glycogenesis through a pathway in which the level of trehalose, the specific blood-sugar of insects, is homeostatically kept constant in Bombyx mori (Yamashita and Hasegawa, 1974) and in Hyalophora cecropia (Wyatt, 1967). It is worth mentioning here that, according to Suzuki et al. (1973), significant activity of fructose-1,6-diphosphatase (FDPase) was detected in the ovaries of Bombyx mori at the middle pupal age, suggesting that the organ is capable of generating glucose also from metabolites other than trehalose. The results of our investigation (Figs. 1 and 2) showed that GGP-DH, NADP-ICDH, ME, HK and PK varied in somewhat similar ways to that for FDPase, permitting the idea that the pupal tissues exhibit wide-ranging interconversions of metabolites. It should be noted here that the whole body extracts were used in the present study, and that, as a matter of course, solely the present data on the levels of enzymatic activities do not reveal how the metabolic pathways are functioning. Distribution of the enzymes and behavior of metabolites among tissues remain to be studied. The kinetic properties of the purified enzymes will also be of value from the viewpoint of metabolic regulation. We, therefore, have tried to purify and characterize some of the enzymes from the pupae of Bombyx mori; the findings have been published separately (Miake et al., 1976; Soeda et al., 1973 ; Torikata, 1974).

\section{REFERENCES}

Bade, M. L. and G. R. Wyatt 1962 Metabolic conversions during pupation of the cecropia silkworm. Biochem. J., 83: 470-478

Chinzei, Y. and S. Tojo 1972 Nucleic acid changes in the whole body and several organs of the silkworm, Bombyx mori, during metamorphosis. J. Insect Physiol., 18: 1683-1698

Ichimasa, Y. 1975 Studies on the mode of action of the diapause hormone with special reference to lipid metabolism in the silkworm, Bombyx mori L. II. Lipid component and 
fatty acid composition of glyceride in pupal ovary, fat body and haemolymph. J. Sericult. Sci. Japan, 44: 137-145

Ichimasa, Y. and K. Hasegawa 1973 Studies on the mode of action of the diapause hormone with special reference to lipid metabolism in the silkworm, Bombyx mori L. 1. Effect of the hormone on lipid in pupal ovaries and matured eggs. J. Sericult. Sci. Japan, 42: 380-392

Kafatos, F. C. 1975 Personal communication.

Kobayashi, M. 1957 Studies on the neurosecretion in the silkworm, Bombyx mori L. Bull. Seric. Exp. Sta. Japan, 15: 181-273

Miake, F., T. Torikata, K. Koga and K. Hayashi 1976 Affinity chromatography of NADPspecific isocitrate dehydrogenase from the pupa of Bombyx mori. Agr. Biol. Chem., 40: 1269-1271

Morishima, I. 1975 Cyclic nucleotide phosphodiesterase in silkworm. Developmental change of cyclic AMP and cyclic GMP phosphodiesterases. Biochim. Biophys. Acta, 403: 106112

Nakasone, Y. and T. Ito 1967 Fatty acid composition of the silkworm Bombyx mori L.J. Insect Physiol., 13 : 1237-1246

Nittono, Y. and Y. Nakasone 1955 Effects of oxygen tensions and carbon monoxide on the respiration of silkworm pupa (Bombyx mori L.). J. Sericult. Sci. Japan, 25: 5-10

Shigematsu, H. and H. Takeshita 1959 On the change in the weight of the fat body and of its chief constituents in the silkworm, Bombyx mori L., during metamorphosis. Jap. J. Appl. Ent. Zool., 3: 123-127

Soeda, E., T. Torikata and S. Akune 1973 Sarcosomal aconitase of silkworm. J. Biochem., 73 : $529-536$

Suzuki, K., 0. Yamashita and K. Hasegawa 1973 On the activity of fructose-1, 6-diphosphatase in pupal ovaries of the silkworm, Bombyx mori L. J. Sericult. Sci. Japan, 42: 357-362

Tojo, S. 1971 Uric acid production in relation to protein metabolism in the silkworm Bombyx mori, during pupal-adult development. Insect Biochem., 1: 249-263

Torikata, T. 1974 Studies on a malate decarboxylase in the pupa of Bombyx mori. "Dissertation, Kyushu Univ."

Walker, P. and E. Bailey 1970 Changes in enzymes associated with lipogenesis during development of the adult male desert locust. J. Insect Physiol., 16: 679-690

Wyatt, G. R. 1967 The biochemistry of sugars and polysaccharides in insects. In "Advances in Insect Physiology," Vol. 4, ed. by J. W. L. Beament, J. E. Treherne and V. B. Wigglesworth, Academic Press Inc., New York, pp. 287-360

Yamashita, 0. and K. Hasegawa 1974 Mobilization of carbohydrates in tissues of female silkworms, Bombyx mori, during metamorphosis. J. Insect Physiol., 20: 1749-1760

Yamashita, O., M. Sumida and K. Hasegawa 1974 Developmental changes in midgut trehalase activity and its localization in the silkworm, Bombyx mori. J. Insect Physiol., 20: 1079. 1085 